\title{
Peran Media Cetak dalam Meningkatkan Partisipasi Politik di Kelurahan Bandar Selamat Kecamatan Medan Tembung Kota Medan
}

\author{
Julia Ivanna1)*, Anita Jojor Pardede ${ }^{1)} \&$ Muhammad Iqbal') $^{2}$
}

\author{
1) Jurusan Pendidikan Pancasila dan Kewarganegaraan, Fakultas Ilmu Sosial, Universitas \\ Negeri Medan, Indonesia \\ 2) Program Studi Pendidikan Antropologi, Fakultas Ilmu Sosial, Universitas Negeri Medan, \\ Indonesia
}

Diterima: Oktober 2018; Disetujui: Oktober 2018; Dipublish: Oktober 2018

*Email: ivannajulia@yahoo.com

\begin{abstract}
Abstrak
Penelitian ini bertujuan untuk mengetahui peran media cetak (surat kabar Analisa) dalam meningkatkan partisipasi politik masyarakat di Kelurahan Bandar Selamat Kecamatan Medan Tembung Kota Medan. Penelitian ini menggunakan metode kuantitatif dengan populasinya yang terdiri dari 12 lingkungan dengan jumlah penduduk 4490 KK. Sampel sebanyak 2 (dua) lingkungan yaitu lingkungan VI berjumlah 527 KK dan Lingkungan X1 berjumlah $178 \mathrm{KK}$, sehingga diperoleh jumlah sampel sebanyak $71 \mathrm{KK}$. Pengambilan sampel dilakukan menggunakan teknik purposive sampling yaitu kedua lingkungan yang mempunyai tingkat membaca surat kabar Analisa yang tinggi. Teknik pengumpulan data dilakukan dengan observasi, angket dan dokumentasi. Untuk menganalisis data, digunakan rumus korelasi product Moment. Berdasarkan hasil penelitian dan analisis data dapat diketahui bahwa hipotesis (Ha) dapat diterima, dengan penafsiran bahwa terdapat pengaruh yang rendah (12\%). Dimana variabel X (peran media cetak 'surat kabar Analisa') sangat baik dinikmati oleh masyarakat di Kelurahan Bandar Selamat, namun disisi lain variabel Y (partisipasi politik masyarakat tergolong rendah). Maka itu dapat dikatakan bahwa peran media cetak dalam meningkatkan partisipasi politik masyarakat tergolong rendah. Berdasarkan hasil pengujian hipotesis ( $\mathrm{Ha}$ ) dapat diterima dengan kesimpulan bahwa ada pengaruh yang rendah terhadap peran media cetak dalam meningkatkan partisipasi politik masyarakat di Kelurahan Bandar Selamat Kecamatan Medan Tembung Kota Medan.
\end{abstract}

Kata Kunci : Peran Media Cetak, Partisipasi Politik Masyarakat

\begin{abstract}
This study aims to determine the role of print media (newspaper analysis) in increasing the political participation of the community in Bandar Selamat sub-district, Medan Tembung sub-district, Medan city. This study uses a quantitative method with a population consisting of 12 environments with a population of 4490 households. The sample is 2 (two) environments, namely environment VI totaling 527 families and environment X1 totaling 178 families, so as to obtain a total sample of 71 families. Sampling was carried out using purposive sampling technique, namely the two environments that have a high reading level of newspaper analysis. Data collection techniques are carried out by observation, questionnaire and documentation. To analyze the data, the product Moment correlation formula is used. Based on the results of research and data analysis it can be seen that the hypothesis ( $\mathrm{Ha}$ ) can be accepted, with the interpretation that there is a low influence (12\%). Where the variable $X$ (the role of the print media "Analysis newspaper") is very well enjoyed by the community in Bandar Selamat Village, but on the other hand the variable $Y$ (the political participation of the community is relatively low). Therefore, it can be said that the role of the print media in increasing the political participation of the community is low. Based on the results of testing the hypothesis ( $\mathrm{Ha}$ ) can be accepted with the conclusion that there is a low influence on the role of the print media in increasing the political participation of the community in Bandar Selamat Village, Medan Tembung Sub-District, Medan City.
\end{abstract}

Keywords: The Role of Print Media, Community Political Participation

How to Cite: Ivanna, J. Pardede, A.J. \& Iqbal, M. (2018). Peran Media Cetak dalam Meningkatkan Partisipasi Politik Di Kelurahan Bandar Selamat Kecamatan Medan Tembung Kota Medan. Journal of Education, Humaniora and Social Sciences (JEHSS). 1 (1): 25-35. 
Julia Ivanna, Anita Jojor Pardede \& Muhammad Iqbal. Peran Media Cetak dalam Meningkatkan Partisipasi Politik Di Kelurahan Bandar Selamat Kecamatan Medan Tembung Kota Medan.

\section{PENDAHULUAN}

Indonesia merupakan salah satu Negara demokrasi, dimana kedaulatan tertinggi berada di tangan rakyat dan rakyat merupakan salah satu agen terpenting dalam kemajuan Negara. Peran masyarakat dapat terlihat ketika masyarakat ikut berpartisipasi di segala bidang salah satunya di bidang politik.

Menurut Herbet Miclosky (dalam Setiadi, 2013) menyatakan bahwa "Partisipasi politik adalah kegiatan-kegiatan sukarela dari warga masyarakat melalui mana mereka mengambil bagian dalam proses pemilihan penguasa, baik secara langsung atau tidak langsung, dalam proses pembentukan kebijakan umum". Oleh karena itu sangat baik jika seluruh rakyat Indonesia ikut berpartisipasi. Untuk dapat mewujudkan partisipasi yang baik maka harus adanya sarana dan prasarana. Sarana dan prasarana yang dapat merangsang partisipasi politik adalah media massa.

Media massa merupakan salah satu sarana yang dijadikan sebagai perpanjangan lidah dan tangan yang berjasa meningkatkan kapasitas manusia untuk mengembangkan struktur sosialnya. Peran media massa khususnya dalam kehidupan politik tidak diragukan lagi. Media massa sangat berperan dalam perkembangan atau bahkan perubahan pola tingkah laku dari suatu masyarakat. Oleh karena itu kedudukan media massa dalam masyarakat sangat penting. (McQuail, 2000).

Hasanuddin,dkk, (2015) menyatakan bahwa: "Media massa mampu mempengaruhi tindakan dan pemikiran khalayak antara lain dalam hal budaya, sosial, dan politik. Hal ini menjadi sangat penting dalam setiap kampanye politik. Cakupan yang luas dalam masyarakat membuat media massa dianggap sebagai salah satu cara yang efektif dalam mengkomunikasikan program kerja, pesan politik kepada konsumen pembaca".

Berdasarkan uraian di atas terlihat jelas betapa besar peran media massa sebagai alat komunikasi. Seperti halnya menurut Jallaludin Rakhmat, 2005 (dalam Tabroni, 2014) menyatakan bahwa: "Media massa seringkali dipandang sebagai alat kekuasaan yang efektif karena kemampuannya untuk membujuk pendapat dan anggapan serta mendefinisikan dan membentuk persepsi terhadap realitas". Sedangkan menurut Crowaford yang dikutip Ida (2014) (dalam Hasanuddin, Vol 5 No.1 jurnal Peran Media Massa Dalam Meningkatkan Partisipasi Pemilih Pemula Pada Pilkada 2013 Di Kecamatan Tempe Kabupaten Wajo) mengemukakan bahwa :

Media massa dapat dibagi menjadi dua jenis yaitu: media massa modern dan media tradisional. Yang dimaksud media massa modern adalah media massa yang menggunakan teknologi modern yaitu media cetak (Surat kabar, majalah, modul, dll) dan media elektronik (TV, HP, Radio, Komputer, dll) serta media online (blog, facebook, Wikipedia, google, instagram, dll). Sedangkan media tradisional yaitu sarana penyampaian informasi pada zaman dulu, yang lebih banyak menggunkan media massa tradisional misalnya wayang, lawak, lenong dan seni tradisional lainya.

Dalam penulisan ini yang akan dibahas secara mendalam yaitu media cetak seperti surat kabar. Surat kabar merupakan salah satu sarana komunikasi politik yang memiliki peran penting dalam menyampaikan informasi secara timbal balik antara pemerintah dengan masyarakat, masyarakat dengan individu dan surat kabar mampu menyajikan berita yang lebih akurat, lengkap, dan mendalam.

Surat kabar yang juga dikenal sebagai Koran dibagi menjadi dua bagian yaitu Koran dalam cakupan nasional (Harian Indonesia, Jurnal Nasional, Bisnis Indonesia, Rakyat Merdeka, dll) dan Koran dalam cakupan lokal sumatera (Analisa, Waspada, Sinar Baru Indonesia, Pos Metro Medan, Harian Andalas, dll). Surat kabar yang menjadi kajian dalam peningkatan partisipasi politik ialah surat kabar Analisa. http://diskominfo.sumutprov.go.id/bidang_puhk/seksi_hk/daftar_media cetak dan nmedia online_2014.pdf. Alasan pemilihan surat kabar Analisa dilihat dari tingkat berlanganan terhadap surat kabar Analisa yang tinggi oleh masyarakat Kelurahan Bandar Selamat serta surat kabar Analisa juga mempunyai moto "Membangkitkan Partisipasi Rakyat Dalam Pembangunan". Motto tersebut sejalan dengan pembahasan dalam penelitian ini.

Surat kabar seperti halnya Analisa seringkali dimanfaatkan untuk mensosialisasikan visi dan misi dari kandidat yang mengikuti pemilu, memberikan informasi selengkap dan semenarik mungkin terkait dengan program-program jangka panjang dan pendek sebagai perwujudan pelaksanaan visi dan misi para kandidat, memberikan liputan dalam kolom reguler maupun kolom khusus terkait dengan kampanye mereka, menyampaikan biografi dan karya-karya para kandidat berikut rencana kerja mereka (Tabroni, 2014).

Selain hal tersebut diatas, informasi surat kabar juga mempunyai kekuatan bagi kalangan tertentu, khususnya bagi golongan berpendidikan. Informasi ataupun data dalam bentuk cetak sangat digemari karena sifatnya yang lama dalam pengertian bahwa, informasi yang dipublikasikan tersebut bisa disimpan tanpa harus melakukan recording dan kemudian informasi tersebut bisa dengan mudah didapatkan kembali sewaktu-waktu diperlukan dan juga pada umumnya isu-isu dan fakta yang disajikan merupakan

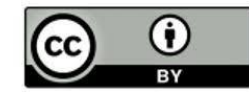


hasil suatu observasi dan analisis yang cukup mendalam dan representatif yang bisa menjadi acuan bagi mereka sendiri maupun untuk kepentingan lainnya (Tabroni, 2014).

Selain itu, hal serupa juga dinyatakan oleh William (2003) (dalam Tabroni, 2014) bahwa "Secara umum berdasarkan kesimpulan dari berbagai studi, orang berpendidikan tinggi lebih menyukai media cetak atau media bacaan dibandingkan dengan media siaran, sedangkan mereka yang berpendidikan menengah lebih menyukai televisi dan radio". Maka dapat dikatakan bahwa surat kabar mempunyai pengaruh bagi dunia perpolitikan. Tetapi disisi lain apakah dengan peran surat kabar dalam dunia politik dapat bersamaan menigkatkan partisipasi politik bagi para konsumen surat kabar?

Kenyataan yang terjadi mengenai partisipasi politik saat ini masihlah dianggap lemah dimana tidak banyak masyarakat ikut serta dalam berbagai aktivitas politik, seperti halnya ikut andil dalam pengambilan keputusan, membuat sebuah kebijakan demi kepentingan bersama, ikut dalam pelaksanaan pendidikan politik yang diadakan para aktor politik dan banyak lagi partisipasi lainnya dalam bidang politik yang mana masyarakat belum memberikan sumbangsihnya demi mewujudkan budaya partisipastif. Rendahnya partisipasi politik dikarenakan rendahnya kesadaran politik masyarakat di Kelurahan Bandar Selamat Kecamatan Medan Tembung.

Menurut Jeffry (2007) dalam Fatwa (2016) bahwa:

"Variabel penting yang mempengaruhi tinggi rendahnya tingkat partisipasi politik seseorang, yaitu kesadaran politik. Jadi, jika individu memiliki kesadaran politik maka ia akan memiliki kesadaran posisi dirinya dalam sebuah tatanan kehidupan bernegara. Salah satu wujud dari kesadaran politik dalam kegiatan pemilu/pilkada".

Maka untuk meningkatkan kesadaran politik bagi masayarakat media cetak sepertihalnya surat kabar memberikan sumbangsihnya berupa peran dalam menyampaikan informasi, mendidik dan mempengaruhi, terkhusus dalam bidang politik.

\section{METODE PENELITIAN}

Metode penelitian pada hakikatnya adalah suatu cara yang sistematis yang dilakukan dalam memecahkan masalah penelitian yang menyangkut apa dan bagaimana penelitian itu dilakukan.

Surakhman (2003) (dalam Yunita, 2016) menyatakan bahwa:

"Metode merupakan suatu cara utama yang digunakan untuk mencapai suatu acuan misalnya untuk menguji serangkaian hipotesis dengan mempergunakan teknik serta alat-alat tertentu. Cara utama itu dipergunakan seteleh si penyelidik memperhitungkan kewajaran yang ditinjau dari tujuan penyelidikan".

Penelitian ini bertujuan untuk mendapatkan gambaran bagaimana Peran Media Cetak Dalam Meningkatkan Partisipasi Politik Di Kelurahan Bandar Selamat Kecamatan Medan Tembung Kota Medan. Pola pikir sangat penting, dimana masyarakat sebagai warga Negara, mempunyai kedaulatan penuh bagi kelangsungan hidup berbangsa dan bernegara.

Lokasi Penelitian ialah tempat penelitian yang akan dilaksanakan. Penelitian ini akan dilaksanakan di Kelurahan Bandar Selamat Kecamatan Medan Tembung Kota Medan. Lokasi penelitian dipilih memiliki pertimbangan-pertimbangan seperti halnya dekat dengan lokasi tempat tinggal penulis, masyarakat di Kelurahan Bandar Selamat Kecamatan Medan Tembung Kota Medan masih menggunakan surat kabar sebagai alternatif dalam mendapatkan informasi.

Menurut Arikunto (2006) mengatakan populasi adalah keseluruhan subjek diteliti, apabila seseorang ingin meneliti semua elemen yang ada dalam wilayah penelitiannya merupakan populasi. Untuk mendapatkan data-data yang akurat dalam sebuah penelitian, maka diperlukan populasi objek penelitian. Yang menjadi populasi dalam penelitian ini adalah Masyarakat Di Kelurahan Bandar Selamat Kecamatan Medan Tembung Kota Medan yang berjumlah 4890 KK yang terbagi kedalam 12 lingkungan.

Menurut Arikunto (2006) mengatakan "sampel adalah sebagian atau wakil populasi yang diteliti. Maka itu sampel pada penelitian ini ialah lingkungan V1 dengan jumlah KK sebanyak 527 dan lingkungan X1 dengan jumlah KK sebanyak 178. Sampel diambil secara Purposive Sampling . Dengan demikian jumlah sampel pada penelitian ini adalah $71 \mathrm{KK}$ di dua lingkungan tersebut dengan pertimbangan tingkat membaca yang tinggi terhadap surat kabar Analisa oleh masyarakat di lingkungan VI dan XI Kelurahan Bandar Selamat Kecamatan Medan Tembung Kota Medan.

Penelitian ini memiliki variabel ganda, adapun yang menjadi variabel dalam penelitian ini adalah vaiabel $\mathrm{x}$ yaitu peran surat kabar Analisa dan variabel y partisipasi politik mayarakat terkhususnya mayarakat di Kelurahan Bandar Selamat Kecamatan Medan Tembung, Kota Medan.

\section{Definisi Operasional}

Menurut Syahrum dan Salim (2009) (dalam Yunita, 2016) menyatakan bahwa "Definisi operasional adalah definisi yang didasarkan atas sifat-sifat yang dapat diamati". 
Sebagaimana telah dijelaskan sebelumnya bahwa penelitian ini menggunakan dua variabel. Agar tidak terjadi kesalahan dalam memahami penelitian ini, maka diberikan definisi operasional sebagai berikut:

Peran media cetak (surat kabar Analisa) adalah sebagai catatan tertulis yang mampu merekam peristiwa/kejadian di massa lampau meskipun peristiwa itu sudah terjadi beberapa puluhan tahun yang lalu, namun masih bisa diperoleh dan dinikmati oleh pembaca serta berperan dalam memberikan informasi, menghibur, memberikan pendidikan serta mempengaruhi pola pikir dan tindakan masyarakat yang membaca surat kabar Analisa sebagai alternatif bacaan.

Partisipasi politik merupakan tindakan politik atau perilaku politik terjadi sebagai refleksi dari citra, sikap dan opini politik sebagai bentuk efek motorik komunikasi politik terhadap warga Negara selaku khalayak politik.

\section{Instrumen Penelitian}

Instrumen yang digunakan dalam penelitian ini adalah lembar observasi, angket dan dokumentasi. Yang mana angket akan dijabarkan dari dua variabel yang digunakan untuk mendapatkan kedalaman data yang diperlukan dari masyarakat di Kelurahan Bandar Selamat Kecamatann Medan Tembung, Kota Medan. Kisi-kisi dalam penelitian ini ialah sebagai berikut:

\begin{tabular}{|c|c|c|}
\hline Variabel & Indikator & Item \\
\hline Peran Media Cetak (Surat & Menyampaikan Informasi & $2,3,4$ \\
\hline kabar Analisa) & Edukasi & 5,6 \\
\hline \multirow[t]{2}{*}{ Varibel X } & Menghibur & 7 \\
\hline & Mempengaruhi & $8,9,10$ \\
\hline Partisipasi Politik & Pemungutan Suara & $1,2,3$ \\
\hline \multirow[t]{4}{*}{ Variabel Y } & Diskusi Politik & 4,5 \\
\hline & Kegiatan Kampanye & $6,7,8$ \\
\hline & $\begin{array}{l}\text { Membentuk dan bergabung dalam } \\
\text { kelompok kepentingan }\end{array}$ & 9 \\
\hline & $\begin{array}{l}\text { Komunikasi individual dengan pejabat } \\
\text { politik }\end{array}$ & 10 \\
\hline
\end{tabular}

\section{Teknik Pengumpulan Data}

Mengadakan pengamatan atau peninjauan secara langsung di Kelurahan Bandar Selamat Kecamatan Medan Tembung Kota Medan untuk melihat situasi atau keadaan yang sebenarnya dalam masyarakat tentang peran media cetak dalam meningkatkan partisipasi politik.

Angket yang digunakan dalam penelitian ini untuk mendapatkan data-data dari responden tentang pribadinya atau hal-hal yang diketahui responden mengenai permasalahan yang diteliti. Angket tersebut disebarkan langsung kepada masyarakat Kelurahan Bandar Selamat Kecamatan Medan Tembung Kota Medan yang menjadi sampel penelitian. Angket yang disusun masing-masing terdiri dari beberapa item atau pertanyaan dan setiap pertanyaan terdiri dari tiga jenis option atau pilihan jawaban.

Arikunto (2006) menyatakan bahwa "metode dokumentasi yaitu mencari data mengenai variabel yang berupa catatan, transkip, buku, surat kabar, majalah, prasasti, notulen rapat, agenda dan sebagainya. Data yang diperoleh melalui dokumentsai ialah seperti transkip jumlah data penduduk di Kelurahan Bandar Selamat Kecamatan Medan Tembung Kota Medan.

\section{Teknik Analisis Data}

Teknik Analisis data yang digunakan dalam penelitian ialah dengan mengunakan teknik analisis korelasi yaitu dengan rumus korelasi product Moment oleh Perason yaitu sebagai berikut (Arikunto, 2013):

Rumus Korelasi Product Moment

$$
r_{x y}=\frac{N \sum X Y-\left(\sum X\right)\left(\sum Y\right)}{\sqrt{\left\{n \sum X^{2}\left(\sum X\right)^{2}\right\}\left\{\sum Y^{2}-\left(\sum Y\right)^{2}\right\}}}
$$

Keterangan :

rxy : Koefisien Korelasi

$\mathrm{N}$ : Jumlah individu dalam sampel

X : Skor Varibel X (Peran Surat Kabar Analisa)

Y : Skor Variabel Y (Partisipasi Masyarakat) 
${ }^{\Sigma} \mathrm{X} \quad$ : Jumlah skor distribusi $\mathrm{X}$

$\Sigma_{\mathrm{Y}}$ : Jumlah skor distribusi $\mathrm{Y}$

${ }^{\Sigma}$ XY : Jumlah skor X dikali Y

${ }^{\Sigma}$ X2 : Jumlah kuadrat skor distribusi X

$\Sigma_{\text {Y2 : Jumlah kuadrat skor distribusi Y }}$

\section{Uji Hipotesis}

Untuk menguji hipotesi peran media cetak dalam meningkatkan partisipasi masyarakat di Kelurahan Medan Bandar Selamat Kecamatan Medan Tembung Kota Medan digunakan rumus uji t, yaitu :

$$
\mathrm{t}=\mathrm{r} \frac{\sqrt{n-2}}{\sqrt{1-r}_{2}} \mathrm{db}=\mathrm{n}-2
$$

Oleh : Supranto dan Limakrisna (103:98)

Untuk mengetahui besar pengaruh variabel $\mathrm{X}$ dan variabel $\mathrm{Y}$ dapat dihitung rumus $\mathrm{Y}=\mathrm{a}+\mathrm{BX}$

$$
\begin{aligned}
& \left.\alpha=\left(\stackrel{\Sigma}{(\Sigma}_{Y}\right)\left({ }^{\Sigma} \mathrm{X} 2\right)-(\stackrel{\Sigma X}{X})^{\Sigma}\right)\left({ }^{\Sigma} \mathrm{XY}\right) \\
& \mathrm{N}^{\Sigma} \mathrm{X} 2-^{\Sigma}(\mathrm{X}) 2 \\
& \mathrm{~b}=\mathrm{N} \stackrel{\Sigma}{\mathrm{XY}}-(\underbrace{\Sigma \mathrm{X})(\Sigma \mathrm{Y})} \mathrm{X})\left({ }^{\Sigma} \mathrm{Y}\right) \\
& \mathrm{N}^{\Sigma \mathrm{X}_{2-}}{ }^{\Sigma}(\mathrm{X}) 2
\end{aligned}
$$

Kemudian dilanjutkan dengan rumus koefisien determinasi guna mengetahui secara jelas besar koefisien korelasi antara kedua variabel yaitu:

$$
\begin{aligned}
& \mathrm{r} 2= \mathrm{b}\left\{\left(\mathrm{N}^{\Sigma \underline{\Sigma}^{\Sigma}} \mathrm{xy}\right)-\left(\underline{\Sigma x}_{\mathrm{x}}\right)\left({ }^{\Sigma} \mathrm{y}\right)\right. \\
& \mathrm{N}\left(\mathrm{(}^{\Sigma} \mathrm{y} 2\right)-\left({ }^{\Sigma} \mathrm{y}\right) 2
\end{aligned}
$$

Keterangan :

$\mathrm{t}=\mathrm{t}$ hitung yang selanjutnya dikonsultasikan dengan $\mathrm{t}$ table

$r=$ koefisien KOrelasi

$\mathrm{N}=$ Jumlah Sampel

r2 = Kuadrat dari koefisien korelasi

Atau dengan kata lain apabila ' $\mathrm{t}$ ' hitung lebih besar dari ' $\mathrm{t}$ ' tabel (thitung $<$ ttabel) pada taraf kepercayaan $95 \%$ dan alpha 5\% maka hipotesis kerja (Ha) yang diajukan dalam penelitian ini diterima. Selanjutnya apabila ' $t$ ' hitung lebih kecil dari ' $t$ ' tabel (thitung $>$ ttabel) maka hipotesis kerja (Ha) ditolak dan (Ho) diterima.

\section{HASIL DAN PEMBAHASAN}

\section{Masyarakat yang Berlanganan Surat Kabar Analisa}

Masyarakat di Kelurahan Bandar Selamat Kecamatan Medan Tembung dilingkungan VI dan XI dari 71 orang responden yang dijadikan sebagai sampel dalam penelitian ini berlangganan surat kabar Analisa, hal tersebut dapat dilihat dari beberapa kartu berlangganan surat kabar Analisa sebagai berikut: 
Julia Ivanna, Anita Jojor Pardede \& Muhammad Iqbal. Peran Media Cetak dalam Meningkatkan Partisipasi Politik Di Kelurahan Bandar Selamat Kecamatan Medan Tembung Kota Medan.
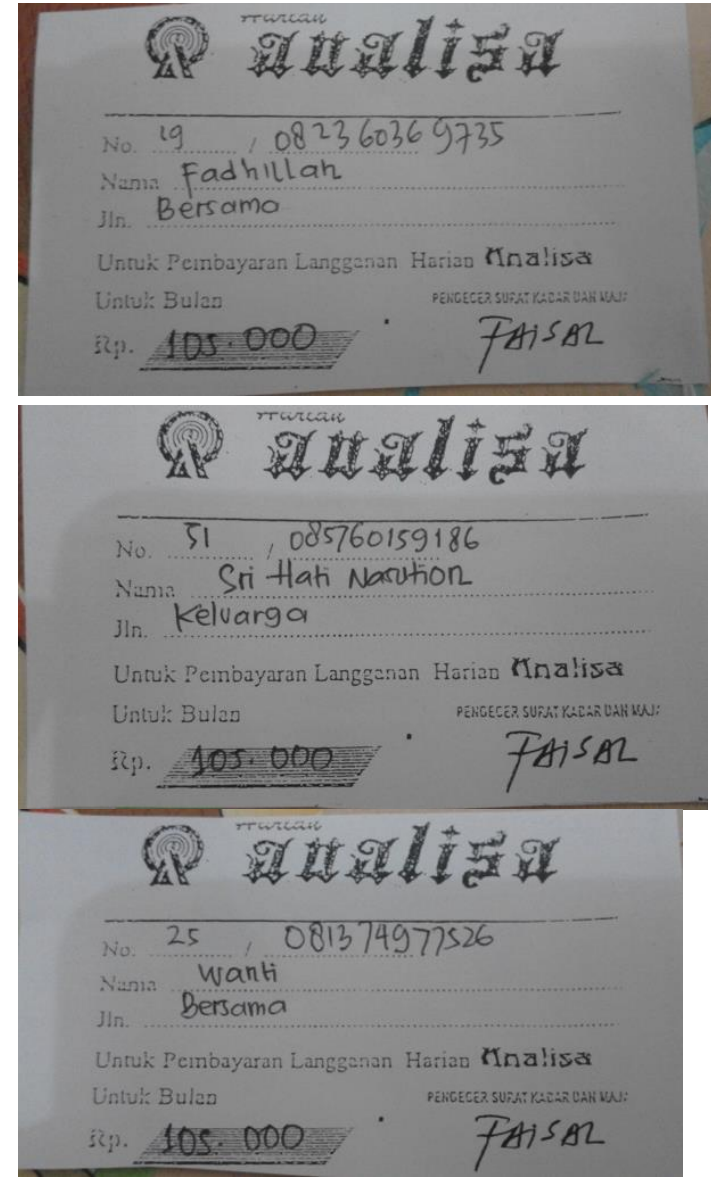

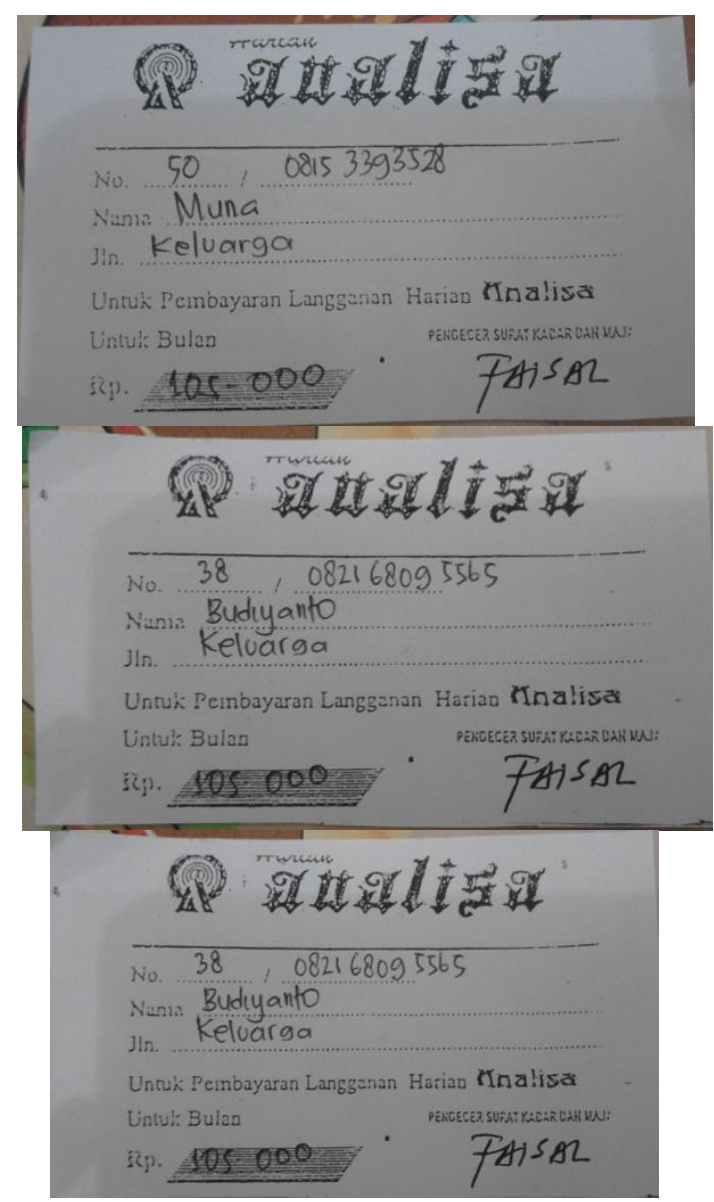

Gambar 1 : Kartu Tanda Berlangganan Surat Kabar Analisa

\section{Mengamati aktivitas masyarakat membaca surat kabar Analisa}

Observasi dilakukan di lokasi penelitian yaitu masyarakat di Kelurahan Bandar Selamat Kecamatan Medan Tembung Kota Medan. Dimana observasi dilakukan dalam rangka pengambilan jumlah penduduk di Kelurahan Bandar Selamat Kecamatan Medan Tembung Kota Medan dan pengambilan gambar masyarakat dalam membaca surat kabar Analisa. Dimana dapat dilihat pada gambar berikut
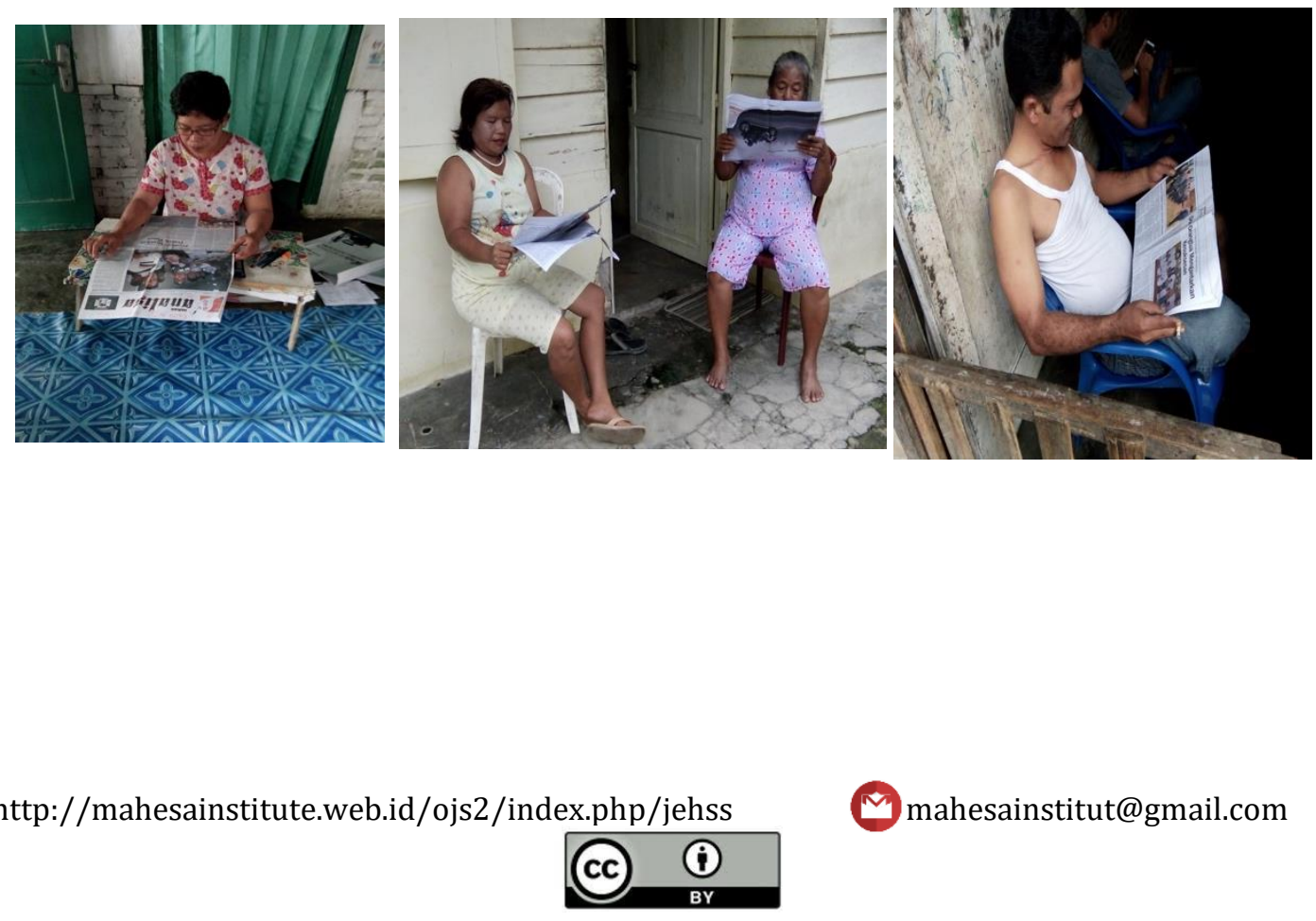

This work is licensed under a Creative Commons Attribution 4.0 

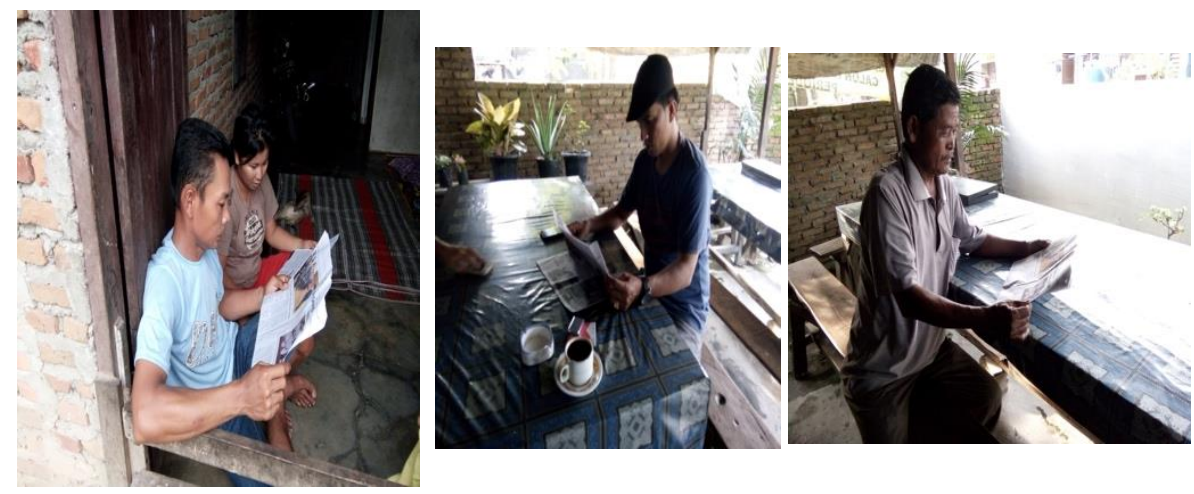

Gambar 2 : Aktivitas Masyarakat Kelurahan Bandar Selamat Kecamatan Medan Tembung Saat Membaca Surat Kabar Analisa

Sumber : Masyarakat Kelurahan Bandar Selamat Kecamatan Medan Tembung
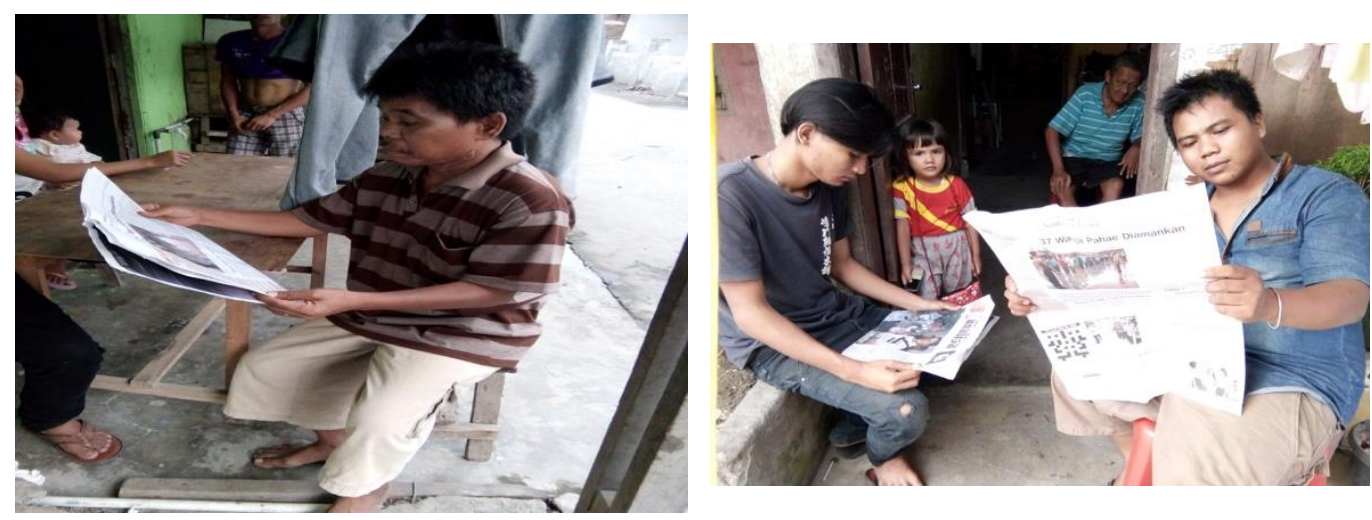

Gambar 2 : Aktivitas Masyarakat Kelurahan Bandar Selamat Kecamatan Medan Tembung Saat Membaca Surat Kabar Analisa

Sumber : Masyarakat Kelurahan Bandar Selamat Kecamatan Medan Tembung

Dari gambar di atas menunjukan bahwa masyarakat di Kelurahan Bandar Selamat Kecamatan Medan Tembung Kota Medan, terkhususnya pada masyarakat di lingkungan VI dan lingkungan XI masih menggunakan surat kabar Analisa sebagai bahan bacaan masyarakat untuk mendapatkan informasi mengenai berbagai isu-isu yang disajikan terkhusunya isu mengenai politik.

Negara Indonesia adalah Negara yang telah mengikrarkan dirinya sebagai Negara Demokrasi. Dimana sistem pemerintah yang telah mengikutsertakan rakyat untuk mencapai kesepakatan dalam sebuah kebijakan. Sistem pemerintahan ini sering disebut dengan istilah "pemerintahan dari rakyat, oleh rakyat dan untuk rakyat". Dari kalimat tersebut telah jelas bahwa rakyat merupakan sistem yang sangat fundamental dalam mengokohkan Negara demokrasi. Keterlibatan rakyat dalam mencapai kebijakan dalam suatu pemerintah harus memiliki pemahaman yang baik mengenai politik, dengan pemahaman politik yang tepat maka keikutsertaannya dalam proses politik juga akan tersistem dengan sempurna, baik itu dalam pembuatan keputusan politik maupun keikutsertaannya dalam pelaksanaan politik.

Pemahaman politik merupakan tingkat pengetahuan yang dimiliki oleh seorang atau kelompok masyarakat tentang politik. Pengetahuan yang dimaksudkan disini adalah fungsi dan peranannya baik sebagai subjek maupun objek dalam aktivitas politik salah satunya ialah partisipasi politik. Sebagaimana kita ketahui partisipasi politik merupakan tindakan politik atau perilaku politik terjadi sebagai refleksi dari citra, sikap dan opini politik sebagai bentuk efek motorik komunikasi politik terhadap warga Negara selaku khalayak politik. Hal serupa juga dinyatakan oleh Herbert McCloky dalam (Setiadi,2013:129) menyatakan bahwa partisipasi politik adalah kegiatan-kegiatan sukarela warga masyarakat melalui mana mereka mengambil bagian dalam proses pemilihan penguasa, dan secara langsung atau tidak langsung dalam proses pembentukan kebijakan umum (public policy). Maka dapat disimpulkan bahwa partisipasi politik merupakan wujud nyata demokrasi dalam aktivitas politik.

Dalam mewujudkan partisipasi yang baik maka kita memerlukan sarana pendukung atau pendorong unutuk memicu lahirnya partisipasi politik atau menambah semangat untuk ikut berpartisipasi. Banyak berbagai instrument yang dapat digunakan dalam mewujudkan partisipasi politik salah satunya ialah media massa. Media massa kini sudah banyak menjangkau berbagai lapisan masyarakat serta memiliki 
kekuatan khusus bagi dunia perpolitikan maka itu tak jarang aktor ataupun elit politik menggunakan media massa sebagai bahan pencitraan mereka. Media massa yang penulis maksud disini ialah media cetak yang kemudian dikhususkan lagi menjadi surat kabar dengan cangkupan lokal dan dipilihlah surat kabar Analisa sebagai instrument pendukung dalam meningkatkan partisipasi politik masyarakat.

(Siska Sasmita, 2011, Vol 2 No 1) Menyatakan terdapat empat teori untuk menjelaskan ada tidaknya pengaruh media massa terhadap politik, yaitu: (1) Teori Penguatan Teori ini berpendapat bahwa pengaruh media massa itu minimal. Apa yang dilakukan oleh media massa pada dasarnya tidak lebih dari sekedar refleksi dan penguatan opini yang terjadi di dalam masyarakat. (2) Teori Setting Agenda, di dalam teori ini, media massa dianggap tidak dapat menentukan apa yang kita pikirkan. Tetapi, media massa dianggap dapat dan memiliki pengaruh terhadap apa yang kita pikirkan. (3) Teori Primining dan Framing, di dalam pandangan teori priming, media dapat memengaruhi karena lebih fokus pada isu-isu tertentu, bukan yang lain. Sementara itu, di dalam teori framing, media melakukan set up untuk memengaruhi penafsiran pembaca, pemirsa, dan pendengar tentang suatu isu dalam makna tertentu. (4) Teori Efek Langsung, media dipandang memiliki pengaruh langsung pada sikap dan perilaku seseorang, termasuk di dalamnya adalah perilaku politik.

Dari empat teori di atas mengenai pengaruh media massa terhadap politik dan dikaitkan kedalam hasil penelitian penulis maka semua teori diatas mempunyai pengaruh politiknya masing-masing bagi masyarakat di Kelurahan Bandar Selamat Kecamatan Medan Tembung Kota Medan. Misalnya saja dalam teori penguatan, media massa dapat menjadi bahan refleksi bagi masyarakat dalam menangapi sebuah isu, misalnya dalam pilihan angket mengenai pengaruh surat kabar Analisa dalam mempengaruhi pola pikir terhadap isu politik yang dijadikan sebagai tolak ukur dalam memilih pemimpin bangsa, lain halnya dengan teori setting agenda dalam teori ini peran surat kabar dapat mempengaruhi terhadap apa yang kita pikirkan melalui fenomena yang terjadi dan dipubliskan dalam rubrik Analisa.

Adapun teori Primming dan framing memiliki pengaruh yang signifikan terhadap perkembangan politik, teori ini menegaskan bahwa media massa menitik beratkan kepada isu-isu tertentu, misalnya pada saat menjelang Pemilu maka rubrik berita yang ada di surat kabar Analisa secara umum mengambarkan eksistensi aktor politik yang masing-masing mencalonkan diri pada pemilu yang akan datang baik itu pemilihan gubernur bahkan pilpers, melalui teori priming maka secara tidak langsung akan mempengaruhi pola pikir pembaca dalam menafsirkan, menilai bahkan melihat aktor politik mana yang layak menjadi pemimpin selanjutnya, hal inilah yang dinamakan teori framming. Dan yang terakhir ialah teori efek langsung teori ini biasanya dapat dilihat dari terwujudnya tindakan seseorang dalam menangapi suatu isu, misalnya pencoblosan dalam pemilu, demonstrasi terhadap ketimpangan yang terjadi, petisi terhadap ketidak setujuan program pemerintah, diskusi politik terhadap pejabat publik dalam menangapi persoalan politik, melakukan kampanye dalam mewujudkan dukungan kepada aktor politik atau bergabung kedalam kelompok kepentingan untuk dapat mempengaruhi kebijakan pemerintah. Namun disisi lain pengaruh peran media cetak terhadap politik jika ditinjau dari teori efek langsung ini belum sepenunya terjadi karena sebagian orang membaca surat kabar hanya ingin menambah informasi serta mendapatkan edukasi yang tidak lain dari efek teori penguatan, setting agenda dan teori priming dan frimming. Di dalam empat teori tersebut, media massa tidak hanya sekedar sebagai institusi yang merefleksikan realitas, melainkan institusi yang memiliki pengaruh terhadap realitas itu, termasuk di dalamnya pengaruh terhadap pemberian makna terhadap realitas itu.

Pada pembahasan hasil penelitian dengan instrument angket sebagai teknik pengumpulan data maka angket dibagi menjadi dua bagian yakni pertanyaan yang berhubungan dengan variabel " $\mathrm{X}$ " dan pertanyaan yang berhubungan dengan variabel "Y". Variabel "X" adalah Peran media cetak terkhususnya media cetak seperti surat kabar Analisa dan variabel "Y" adalah peningkatan partisipasi politik masyarakat di Kelurahan Bandar Selamat Kecamatan Medan Tembung Kota Medan. Dari hasil jawaban responden terhadap variabel " $\mathrm{X}$ " menyatakan bahwa peran media cetak sangat baik dalam menyajikan informasi bagi masyarakat mengenai isu-isu terkini khususnya mengenai politik. Hal ini didukung dari jawaban responden terhadap variabel X (peran media cetak 'surat kabar seperti Analisa') dapat dirincikan sebagai berikut :

1. Bahwa masyarakat di Kelurahan Bandar Selamat setuju surat kabar Analisa mampu memenuhi kebutuhan masyarakat dalam mendapatkan informasi. Hal ini juga diperkuat terhadap presentase jawaban dari 71 responden yang menjwab selalu sebanyak $25 \%$.

2. Bahwa masyarakat di Kelurahan Bandar Selamat setuju Surat Kabar Analisa mampu memberikan perkembangan politik di suatu wilayah terkhusus bagi masyarakat di Kelurahan Bandar Selamat. Hal ini juga diperkuat terhadap presentase jawaban dari 71 orang responden yang menjawab selalu sebanyak $27 \%$. 
3. Masyarakat setuju bahwa dengan membaca surat kabar Analisa mampu memberikan pendidikan politik terhadap isu-isu terkini mengenai politik secara khususnya. Hal ini diperkuat terhadap presentase jawaban dari 71 orang responden yang menjawab selalu sebanyak 23,43\%.

4. Masyarakat di Kelurahan Bandar Selamat Kecamatan Medan Tembung setuju kalau dengan membaca surat kabar Analisa mampu menyajikan berita terkini atau teraktual mengenai politik. Hal ini diperkuat terhadap presentase jawaban dari 71 orang responden yang menjawab selalu sebanyak $27 \%$.

Dari analisis data di atas maka peran media cetak sepenuhnya dinikmati oleh masyarakat dan memiliki pengaruh yang baik, hal ini terbukti dari presentase jawaban responden yang mencapai $20 \% \mathrm{ke}$ atas.

Adapun peran media cetak menurut McQuail, 2000, (Setiawan dalam artikel "Peran Media Massa Dalam Meningkatkan Kualitas Kepemerintahan Lokal Berbasis Human Security Di Kota Jayapura") menyatakan bahwa : "Ada enam persepektif dalam melihat peran media yaitu:

1. Melihat media massa sebagai window on event and experience, media dipandang sebagai jendela yang memungkinkan khalayak melihat apa yang sedang terjadi diluar sana. Atau media merupakan sarana belajar untuk mengetahui berbagai peristiwa.

2. Media juga sering dianggap sebagai a mirror of events in society and the world, implying a faithful reflection. Yaitu, cermin berbagai peristiwa yang ada dimasyarakat dan dunia yang merefleksikan apa adanya.

3. Memandang media massa sebagai filter atau gatekeeper yang menyeleksi berbagai hal untuk diberi perhatian atau tidak. Media senantiasa memilih isu, informasi atau bentuk content yang lain berdasar standar para pengelolannya. Disini khalayak "dipilhkan" oleh media tentang apa-apa yang layak diketahui dan mendapat perhatian.

4. Media massa sesekali pula dipandang sebagai guide, penunjuk jalan atau interpreter, yang menerjemahkan dengan menunjukkan arah atas berbagai ketidakpastian atau alternatif yang beragam.

5. Melihat media massa sebagai forum untuk mempresentasikan berbagai informasi dan ide-ide kepada khalayak, sehingga mungkin terjadinya tanggapan dan umpan balik.

6. Media massa sebagai interlocutor, yang tidak hanya sekedar tempat berlalu lalangnya informasi, tetapi juga partner komunikasi yang memungkinkan terjadinya komunikasi interaktif.

Berdasarkan penjelasan di atas mengenai peran surat kabar yang dijabarkan menjadi enam bagian yang mana hal-hal tersebutlah yang menguatkan kedudukan surat kabar sebagai salah satu media yang harus diperhitungkan dalam menyebarluaskan proses politik secara khususnya.

Kemudian dari hasil angket yang diteliti pada variabel "Y" yakni peningkatan partisipasi politik melalui media cetak seperti surat kabar analisa menyatakan bahwa mempunyai pengaruh hanya saja pengaruh tersebut tidak terlalu signifikan (rendah) terhadap peningkatan partisipasi politik masyarakat. Hal ini didukung dari jawaban responden terhadap variabel Y (Peningkatan Partisipasi Politik Mayarakat di Kelurahan Bandar Selamat Kecamatan Medan Tembung) dapat dirincikan sebagai berikut :

1. Masyarakat Kelurahan Bandar Selamat Kecamatan Medan Tembung dari 71 orang responden yang menjawab selalu terhadap pengaruh surat kabar Analisa dalam memberikan pengetahuan mengenai visi dan misi kandidat dalam pilkada, terhadap pemberian suara ketika pemilu gubernur tahun 2013 lalu sebanyak $12,07 \%$.

2. Masyarakat Kelurahan Bandar Selamat Kecamatan Medan Tembung dari 71 orang responden yang menjawab selalu terhadap pengaruh promosi peserta pilkada dalam surat kabar Analisa sebanyak $11,36 \%$.

3. Masyarakat Kelurahan Bandar Selamat Kecamatan Medan Tembung dari 71 responden yang menjawab selalu terpengaruh terhadap isu agama dari partai politik untuk ikut memilih dalam pemilu yang akan datang sebanyak $17,04 \%$.

4. Masyarakat Kelurahan Bandar Selamat Kecamatan Medan Tembung dari 71 orang responden yang menjawab selalu terpengaruh terhadap informasi yang disajikan surat kabar Analisa dalam mengambil keputusan politik sebanyak 12,07\%.

5. Masyarakat Kelurahan Bandar Selamat Kecamatan Medan Tembung dari 71 orang responden yang menjawab selalu melakukan diskusi politik terhadap permasalahan yang disajikan dalam kolom berita surat kabar Analisa sebanyak 12,07\%.

6. Masyarakat Kelurahan Bandar Selamat Kecamatan Medan Tembung dari 71 orang responden yang menjawab selalu menemukan iklan mengenai partai politik menjelang pemilu legislatif sebanyak 14,2 $\%$.

7. Masyarakat Kelurahan Bandar Selamat Kecamatan Medan Tembung dari 71 orang responden yang menjawab selalu melihat kolom berita mengenai partai politik dalam pemilu legislatif 2013 melakukan komunikasi politik yang baik kepada masyarakat sebanyak 13,49\%. 
Julia Ivanna, Anita Jojor Pardede \& Muhammad Iqbal. Peran Media Cetak dalam Meningkatkan Partisipasi Politik Di Kelurahan Bandar Selamat Kecamatan Medan Tembung Kota Medan.

8. Masyarakat Kelurahan Bandar Selamat Kecamatan Medan Tembung dari 71 orang responden yang menjawab selalu terdorong melaporkan kepada pihak yang berwajib jika mendapatkan kampanye politik yang curang dari para aktor politik sebanyak 12,07\%.

9. Masyarakat Kelurahan Bandar Selamat Kecamatan Medan Tembung dari 71 orang responden yang menjawab selalu mempunyai keinginan bergabung kedalam kelompok kepentingan ataupun partai politik untuk mempengaruhi keputusan politik sebanyak $10 \%$.

10. Masyarakat Kelurahan Bandar Selamat Kecamatan Medan Tembung dari 71 orang responden yang menjawab selalu terdorong menyuarakan aspirasi-aspirasinya dalam mewujudkan pemerintahan yang baik sebanyak $16,33 \%$.

Berdasarkan pernyataan di atas, dapat dilihat bahwa tingkat partisipasi politik masyarakat di Kelurahan Bandar Selamat Kecamatan Medan Tembung tergolong rendah hal ini didapat dari rata-rata presentase responden yang tidak mencapai presentase 20\% keatas. Padahal disisi lain peran media cetak yang dinikmati oleh masyarakat sangat memiliki pengaruh yang baik, hal ini terbukti dari presentase jawaban responden yang mencapai $20 \%$ ke atas. Dari 10 pertanyaan yang dijawab oleh 71 orang responden maka dapat diklasifikasikan bahwa partisipasi masyarakat secara konvensional tergolong rendah, hal ini dapat dilihat dari :

1. Partisipasi Politik dalam Pemberian suara (votting) tergolong rendah sesuai dengan pertanyaan angket pada item no 3 variabel Y sebanyak 17,04\%.

2. Partisipasi Politik dalam Diskusi politik juga tergolong rendah hal ini sama dengan jawaban responden terhadap item no 5 variabel Y sebanyak 17,04\%.

3. Partisipasi Politik dalam kegiatan kampanye tergolong rendah sesuai dengan jawaban angket pada item no 7 variabel Y sebanyak 13,49\%.

4. Partisipasi politik dalam membentuk dan bergabung dalam kelompok kepentingan juga tergolong rendah hal ini sesuai dengan jawaban responden terhadap item no 9 variabel Y sebanyak $10 \%$.

5. Partisipasi politik terhadap komunikasi individual dengan pejabat politik dan administrasi juga tergolong rendah hal ini sama dengan jawaban responden terhadap item no 10 variabel Y sebanyak $16,33 \%$.

Dari serangkaian kegiatan yang dilaksanakan dan dari analisa data yang telah dilakukan ternyata pengaruh peran media cetak (surat kabar Analisa) sangat baik dinikmati oleh masyarakat di Kelurahan Bandar Selamat Kecamatan Medan Tembung Kota Medan, namun jika dikaitkan kedalam peningkatan partisipasi politiknya tergolong rendah sehingga dapat dikatakan bahwa ada faktor lain yang mungkin mempengaruhi partisipasi politik masyarakat dalam proses politik selain pengaruh dari peranan media cetak (surat kabar 'Analisa').

Dari data yang telah diperoleh dimana " $t$ " hitung lebih besar dari " $t$ " tabel yakni 3,725 > 1,99, ini berarti mengambarkan bahwa hipotesis ( $\mathrm{Ha}$ ) diterima yakni "terdapat korelasi yang rendah atau tidak signifikan antara peran media cetak dalam meningkatkan partisipasi politik masyarakat di Kelurahan Bandar Selamat Kecamatan Medan Tembung Kota Medan. Hal ini sesuai dengan data yang diperoleh dari angket yang dijawab responden sebanyak 71 orang, dimana responden merupakan masyarakat yang berdomisili di Kelurahan Bandar Selamat Kecamatan Medan Tembung Kota Medan.

Menanggapi hal tersebut diatas masyarakat Kelurahan Bandar Selamat Kecamatan Medan Tembung memperlihatkan bahwa peran surat kabar seperti halnya memberikan informasi, memberikan edukasi, menghibur dan mempengaruhi sangat baik diterima oleh masyarakat di Kelurahan Bandar Selamat Kecamatan Medan Tembung Kota Medan, namun jika dikaitkan kedalam peningkatan partisipasi politik peran surat kabar tidak mempunyai pengaruh yang signifikan.

Berdasarkan penjelasan di atas masyarakat di Kelurahan Bandar Selamat Kecamatan Medan Tembung merupakan masyarakat yang dengan cepat menenerima berbagi hal yang baru melalui perkembangan Teknologi sekarang ini, apalagi kalau kita melihat media cetak seperti surat kabar Analisa sekarang ini sudah banyak menjangkau seluruh lapisan masyarakat. Untuk itu dalam mengambil bagiannya media cetak sebagai alternatif bahan bacaan harus mampu mengambil pengaruh dalam membentuk partisipasi politik masyarakat. Namun sayangnya media cetak seperti halnya surat kabar Analisa hanya dijadikan sebagai bahan bacaan dan bahan edukasi tanpa memperaktekan tindakan-tindakn positif yang dibutuhkan pemerintah dari masyarakat seperti halnya menyuarakan ketimpanganketimpangan yang terjadi mnelalui pemberitaan yang diberikan seperti melakukan diskusi politik, komunikasi kepada pejabat serta bergabung kedalam kelompok kepentingan.

Dapat dinyatakan bahwa adanya pengaruh lain yang dapat meningkatkan partisipasi politik masyarakat selain media cetak, salah satunya bisa melalui media online walaupun tingkat kredibelnya lebih tinggi media cetak dibandingkan media online namun disisi penyajian informasi media online menyajikan wwith http://mahesainstitute.web.id/ojs2/index.php/jehss

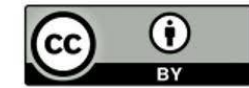


informasi tanpa batas, dapat dinikmati oleh semua kalangan, mudah dibawa kemana saja dan dapat diakses kapanpun.

Pernyataan tersebut terbukti dengan penyebaran angket serta jawaban yang diberikan oleh masyarakat yang dilakukan peneliti, dimana masyarakat menganggap bahwa media cetak hanya sebagai bahan bacaan untuk mengetahui pemberitaan terkini dan untuk mengetahu isu-isu politik yang ada. Masyarakat beranggapan bahwa membaca surat kabar hanya dapat mengigatkan mereka dalam jangka waktu yang singkat sedangkan untuk mengingat informasi dalam waktu yang relatif lama surat kabar belum bisa memperlihatkan hal itu. Hal inilah yang membuat masyarakat tidak menjadikan media cetak sebagai alternatif pendorong peningkatan partsipasi politik masyarakat. Padahal seperti yang kita ketahui bahwa kegiatan-kegiatan khususnya yang berkaitan dengan politik banyak disajikan didalam media cetak dengan tingkat akuransi yang lebih tinggi dibandingkan dengan media online.

Perkembangan media massa (cetak ataupun online) merupakan sarana yang praktis bagi masyarakat dalam mengeksplorisasi segala keinginan dan harapan untuk mencapai hak yang dimiliki serta sebagai alat penyampaian aspirasi masyarakat. fungsi surat kabar harus lebih difokuskan dalam peningkatan partisipasi politik. Fungsi informasi dari media cetak ialah memberikan dan menyampaikan pesan-pesan yang berkaitan dengan politik baik itu kebijakan, visi, misi dan tujuan dari program pemerintah yang langsung disampaikan bagi para pembaca.

\section{SIMPULAN}

Tingginya tingkat membaca masyarakat di Kelurahan Bandar Selamat Kecamatan Medan Tembung Kota Medan terhadap media cetak (Surat Kabar Analisa). Sejalan dengan tingginya tingkat membaca surat kabar Analisa maka adanya pengaruh yang baik dinikmati masyarakat terhadap peran media cetak hal ini sejalan dengan tingkat presentase jawaban responden diatas $20 \%$. Namun disisi lain peran media cetak jika dikaitakan kedalam peningkatan partisipasi politik masyarakat tergolong rendah hal ini dibuktikan dengan jawaban responden dibawah $20 \%$ dan juga ditunjukan melalui penghitungan bahwa yang diperoleh dari perhitungan nilai korelasi 0,383 yang memiliki interprestasi nilai korelasi yang rendah. Berdasarkan hasil korelasi yang rendah antara peran media cetak dalam peningkatan partisipasi politik masyarakat maka dapat dikatakan bahwa adanya pengaruh yang lain dalam peningkatan partisipasi politik salah satunya ialah media online yang mempunyai jaringan akses yang lebih luas yang dapat dinikmati tanpa ruang dan batas.

\section{DAFTAR PUSTAKA}

Arifin, A. (2014). Politik Pencitraan Pencitraan Politik. Yogyakarta: Graha Ilmu.

(2006). Prosedur Penelitian. Jakarta: Rineka Cipta.

Budiardjo, M. (2010). Dasar-dasar Ilmu Politik, cetakan keenam. Jakarta: PT Gramedia Pustaka Utama.

Damsar. (2010). Pengantar Sosiologi Politik. Jakarta: Kencana Prenanda Group.

Effendy, U. (2003). Ilmu, Teori dan Filsafat Komunikasi.Bandung: PT Citra Aditya Bakti.

Halking, B.A.M. (2014). Bahan Ajar Ilmu Politik. Medan: UNIMED. (2012). Bahan Ajar Sistem Politik Indonesia. Medan: UNIMED.

Ida, R \& Henry. (2015). Komunikasi Politik, Media, Dan Demokrasi. Jakarta: Prenada Media Group.

Josephin. (2013). Profil Surat Kabar Soera Dairi Tahun 1930 Di Sidikalang. Medan: Skripsi.

Kamus Besar Bahasa Indonesia. (2008). Edisi Keempat. Jakarta: PT Gramedia Pustaka Utama.

Kolip, U. \& Elly. (2013). Pengantar Sosiologi Politik. Jakarta: Prenada Media Group.

Nasiwan \& Cholisin. (2012). Dasar-dasar Ilmu Politik.Yogyakarta: Ombak.

Setiawan, D. (2014). Metedologi Penelitian.Medan: Laboratorium PPKn FIS Universitas Negeri Medan.

Sitepu, A. (2012). Teori-teori Politik. Yogyakarta: Graha Ilmu

Tabroni, R. (2014). Marketing Politik: Media dan Pencitraan di Era Multipartai. Yogyakarta: Graha Ilmu

Tambruka, A. (2013). Literasi media. Jakarta: PT Rajagrafindo persada.

Hasanuddin, dkk. (2015). Peran Media Massa Dalam Peningkatan Partisipasi Pemilih Pemula Pada Pilkada 2013 Si Kecamatan Tempe Kabupaten Wajo, Jurnal Ilmu Pemerintahan. Vol.5 No.1. Alamat webnya: http://journal.unismuh.ac.id/index.php/Otoritas/article/download/105/97, diakses pada tanggal 14 Febuari 2017 pada pukul 14.00 wib.

Lestaluhu, S. (2015). Peran Media Cetak Dalam Mengawal Kebijakan Publik Di Kota Ambon, Jurnal Penelitian $\begin{array}{lllll}\text { Komunikasi dan Opini. } & \text { Vol.19 No.1. } & \text { Alamat }\end{array}$ https://jurnal.kominfo.go.id/index.php/jpkop/article/download/332/268, diakses pada tanggal 15 Desember 2016 pada pukul 15:04 wib.

Sasmita, S. (2011). Peran Informasi Politik Terhadap Partisipan Pemilih Pemula Dalam Pemilu/Pemilukada, Jurnal Ilmiah Administrasi Publik dan Pembangunan. Vol 2 No 1. Alamat webnya: http://ejournal.undip.ac.id/index.php/politika/article/viewFile/5096/4622.html diakses pada tanggal 13 Desember 2016 pada pukul 09:58 wib.

http://kbbi.web.id/persepsi, diakses pada tanggal 21 Febuari 2017, pada pukul $16.00 \mathrm{wib}$

http://id.wikipedia.org/wiki/persepsi, diakses pada tanggal 21 Febuari 2017, pada pukul 15.50 wib. 
Julia Ivanna, Anita Jojor Pardede \& Muhammad Iqbal. Peran Media Cetak dalam Meningkatkan Partisipasi Politik Di Kelurahan Bandar Selamat Kecamatan Medan Tembung Kota Medan.

https://googleweb..m/2012/08/kekuatandankelemahansuratkabar), diakses pada tanggal 21 febuari 2017 pada pukul 20:04 wib.

http://www.romelteamedia.com/2016/01/media-cetak-lebih-kredibel- ketimbang-online.html, diakses pada tanggal 27 Febuari 2017 pada pukul 19.04 wib 